\title{
Features of state regulation of exports in developing countries and their modernization
}

\author{
Antonina Sharkova ${ }^{1,{ }^{*}}$ and Irina Sycheva ${ }^{2}$ \\ ${ }^{1}$ Financial University under the Government of the Russian Federation, 49, Leningradsky, 125993, \\ Moscow, Russia \\ ${ }^{2}$ Head of the Foreign Trade Department, Hermes Coffee Company Ltd, Moscow, Russia
}

\begin{abstract}
The article describes the features of state influence in the export of coffee from Africa, affecting the international trade in raw materials. The example of coffee market is analyzed in the article. The world experience of regulating the flow of goods from a country with a transition economy is analyzed and its adaptation to developing countries is evaluated. The problem of this industry is expressed in the fact that after centuries, African countries have not been able to develop an optimal model for regulating coffee exports in the context of the formation of raw material prices on international exchanges. The purpose of the study is to assess the possibility of adapting on the African continent the Russian model of state support for exports, which is a system of a number of institutions focused on the implementation of subsidy programs through administrative and tax measures. The scientific novelty is that, for the first time, two models of state regulation of developing countries and countries with economies in transition are correlated in order to modernize the African export support system.
\end{abstract}

\section{Introduction}

The history of the spread of coffee around the world began more than a thousand years ago in Ethiopia, when people realized that the berries of this tree have a tonic effect. Around the XV century, the Arabs brought coffee tree seedlings from Ethiopia to Yemen and established the first commercial coffee plantations. Then they began shipping roasted coffee beans all over the world. In the XVII century, Yemen's monopoly on the supply of coffee ceased to exist, as Europeans exported tree seedlings to their African colonies with a suitable climate.

The problem of this industry is expressed in the fact that after centuries, African countries have not been able to develop an optimal model for regulating coffee exports in the context of the formation of raw material prices on international exchanges.

The purpose of the study is to assess the possibility of adapting on the African continent the Russian model of state support for exports, which is a system of a number of institutions focused on the implementation of subsidy programs through administrative and tax measures.

\footnotetext{
*Corresponding author:sharkova_av@mail.ru»
} 
The scientific novelty is that, for the first time, two models of state regulation of developing countries and countries with economies in transition are correlated in order to modernize the African export support system.

\section{Main part}

Currently, African Governments' promotion of coffee trade to national exporters is expressed in measures to restrict free market relations on the continent. The reason for this was the weak experience of living in independent conditions and the lack of the necessary equity capital for the formation of public goods. After disconnecting from the colonist countries, Africans began to create trade unions and associations in order to simplify exports from the continent, however, due to the small experience of independent moderation of raw materials sales processes, development in this area is very slow. After the colonial liberation, Africa began a new export activity, but there was nothing to build on, as there was no foreign funding and support. Exports from the continent were divided by economic and geographical areas - North Africa, sub-Saharan Africa and South Africa, which have differential features of trade turnover and different levels of production diversification.[1] The Governments of each territorial region introduce their own measures to support the export of food products, individually form the volume and price policy of foreign trade, which affects the total export of raw materials from a single continent. This is a deterrent to the increasing importance of Africa's resource and economic potential in the emerging new model of global development of world trade, which is clearly seen in the example of coffee exports.

The first African country in terms of Arabica production and the fifth in the world is Ethiopia. The cultivation, processing and trade of coffee in this country employs $20 \%$ of the population, namely 23 million of people. The country produces 350 thousand tons of coffee a year, which provides a significant part of the state's export revenue. Government regulation of the coffee market in Ethiopia is expressed in economic restrictions and the creation of a unique system for trading raw materials on its own exchange. According to Ethiopian law, foreigners do not have the right to own a business related to coffee production, so all processing and cleaning stations, as well as exporting companies, belong to citizens of the country. The coffee supply chain in this country begins with a farmer who once a year collects and sells berries to buyers who transfer the raw materials to the processing station. Further, dried coffee is formed in the production, if it was a natural processing, or a parchment, if it was washed. The exporter purchases the goods ready for export. He is also looking for a buyer, provides logistics to the port and issues export certificates. After the buyer for the coffee is found and the contract price is fixed, the exporter delivers the sample to the Ethiopian Commodity Exchange (ECX) along with the concluded contract. ECX plays an important role in the coffee industry in Ethiopia. The Ethiopian Commodity Exchange evaluates coffee for compliance with the specified grade in order to control the quality and price and prevent its artificial understatement for the sake of avoiding taxes, since the government charges exporters a duty of $3 \%$ of the contract. The price of coffee is determined by the balance of supply and demand in the current season and is not linked to global trading exchanges. Specialists check the grain for the number of defects, evaluate the taste according to the SCA system and record all the data in summary statistical tables along with the contract price. As a result, statistics are generated. For example, in the 2019/2020 season, the average price for coffee from the Sidamo zone of the second grade with a taste score of 85 points was 5 US dollars per one kilogram. [2] Therefore, if someone tried to export such coffee for 4 US dollars per one kilogram or give out the first grade for the second, they were refused. Thus, in Ethiopia, the main feature of the 
regulation of coffee exports is a fully formed and implemented artificial market model from the purchase to the delivery of goods through the ECX, according to which the participation of foreign capital in the coffee industry in Ethiopia is prohibited. The exchange is a significant obstacle to the participation of Ethiopian coffee sellers in international trade in the commodity, which occurs on the main world exchanges ICE (Intercontinental Exchange), NYMEX (New York Mercantile Exchange) and LIFFE (London International Financial Futures and Options Exchange).

The world leader in the specialty coffee industry is Kenya, thanks to a good terroir and the right approach to production. More than 250 thousand Kenyans are engaged in the cultivation of coffee beans.[3] Most of them work in cooperatives that have direct access to foreign buyers of raw materials. Despite the high global demand for Kenyan coffee, Kenyan farmers are the poorest in the world. This is due to the policy within the cooperatives, according to which the main grain producers receive a minimum share of export revenue. Due to low earnings and the introduction by the Kenyan Government of quantitative restrictions on the cultivation of coffee volumes by one farm, farmers began to occupy the second stage of the export chain, namely, to build their own stations for processing and washing raw materials in order to increase their share of export revenue. Large farms have started selling their finished refined goods directly to foreign buyers. This system allowed farmers to be more independent and make their own decisions on how to process and sell their own coffee. However, only $15 \%$ of the goods produced are sold from the farmer to the final buyer. The main volume is sold through the Government Auction System at the Nairobi Coffee Exchange, which involves three participants: a farmer, a seller, and an exporter. The first grows the product, the second prepares it for sale for export, the third exports it. Such a transparent system facilitates the tracking of raw materials within the country. Before bidding, the exporter tests samples of the coffee offered by the sellers, the producers of which are encrypted, thus eliminating the possibility of direct transactions from farmers for export. After the sale and receiving the money from the exporter, the seller is obliged to transfer the money to the farmer within two weeks. The seller himself receives a fixed commission about 50 US dollars per one ton of coffee for the work. They do not depend on the quality or manufacturer of a particular lot. Thus, the bidding model in Kenya promotes the involvement of more players in the market, namely intermediaries between the producer and the exporter, but the farmers themselves are limited both in the permissible production volumes and in obtaining greater economic benefits, which can lead to a deterioration in the quality of raw materials, in which landowners invest a significant part of the proceeds from sales.

The main African country whose coffee generates half of export revenues is Uganda. In 1930, the Coffee Marketing Board was created, which centrally managed the production of raw materials and established a state monopoly on coffee exports, with the main profit received by the state. Later, between 1971 and 1979, Ugandan food industry declined due to political instability caused by the overthrow of President Milton Obote, and the imposition of high export taxes.[4] This led to the fact that farmers began to receive their earnings without profit and were forced to switch to black market sales, smuggling coffee to neighboring countries. In the years that followed, successive Governments tried to rebuild Ugandan coffee industry. Thus, in 1991, the Uganda Coffee Development Authority was established, whose activities are financed by charging Ugandan exporters a fee of $1 \%$ of the contract value of raw materials. The UCDA is responsible for regulating the industry, namely, controlling the quality of exported coffee and conducting research to improve bean processing methods. The Uganda Coffee Development Authority has the right to implement new programs for the development of the coffee industry within the country, which may indirectly lead, 
among other things, to export restrictions. Thus, following a meeting held on $9^{\text {th }}$ March 2021 between UCDA and coffee traders, processors and exporters, a number of resolutions were adopted regarding the enforcement of coffee quality regulations in the Kasese area and Mount Ruwenzori, the main coffee growing areas in Uganda, particularly:

- Inspection of all processing facilities to ensure compliance with the requirements.

- Suspension of certain types of coffee activities, namely trade and the process of exfoliating beans. This will allow enough time for the berries to fully ripen and thus allow farmers to start harvesting when the coffee is fully ripe. The start date of the harvesting season and the opening of the exfoliation plants will be announced to UCDA later.

- All coffee warehouses that already have stocks of coffee for export will be subject to inspection and the subsequent issuance of a form $\mathrm{V}$ for the goods to continue operating.

- Exporters and husk mills will have to declare all coffee varieties that could have been obtained without Form V in order to update the UCDA database. This will help to ensure effective transparency of all coffee supplies from the Ruwenzori area.

These resolutions have led to a halt in the export of coffee from the Kasese area and the loss of a significant part of the revenue of farmers who do not have the opportunity to stand idle indefinitely and wait for the end of the inspection of the goods by the UCDA.

Thus, in Uganda, a country with a large raw material potential, the success of the coffee industry depends on the balanced implementation by the Government Organization UCDA of coffee export development programs not only in the interests of the state, but also of farmers in order to increase the country's role in international exports.

Restrictive government regulations in Ethiopia, Kenya, and Uganda are reducing the share of African countries in the global coffee trade.

Thus, in recent years, the participation of these States in the international coffee trade has been declining. In 2018, global coffee exports exceeded 17.6 billion US dollars (according to foreign trade statistics of 118 countries). At the same time, the share of Ethiopia, Kenya and Uganda was $5.89 \%$ in 2018 compared to $7.83 \%$ in 2017. 


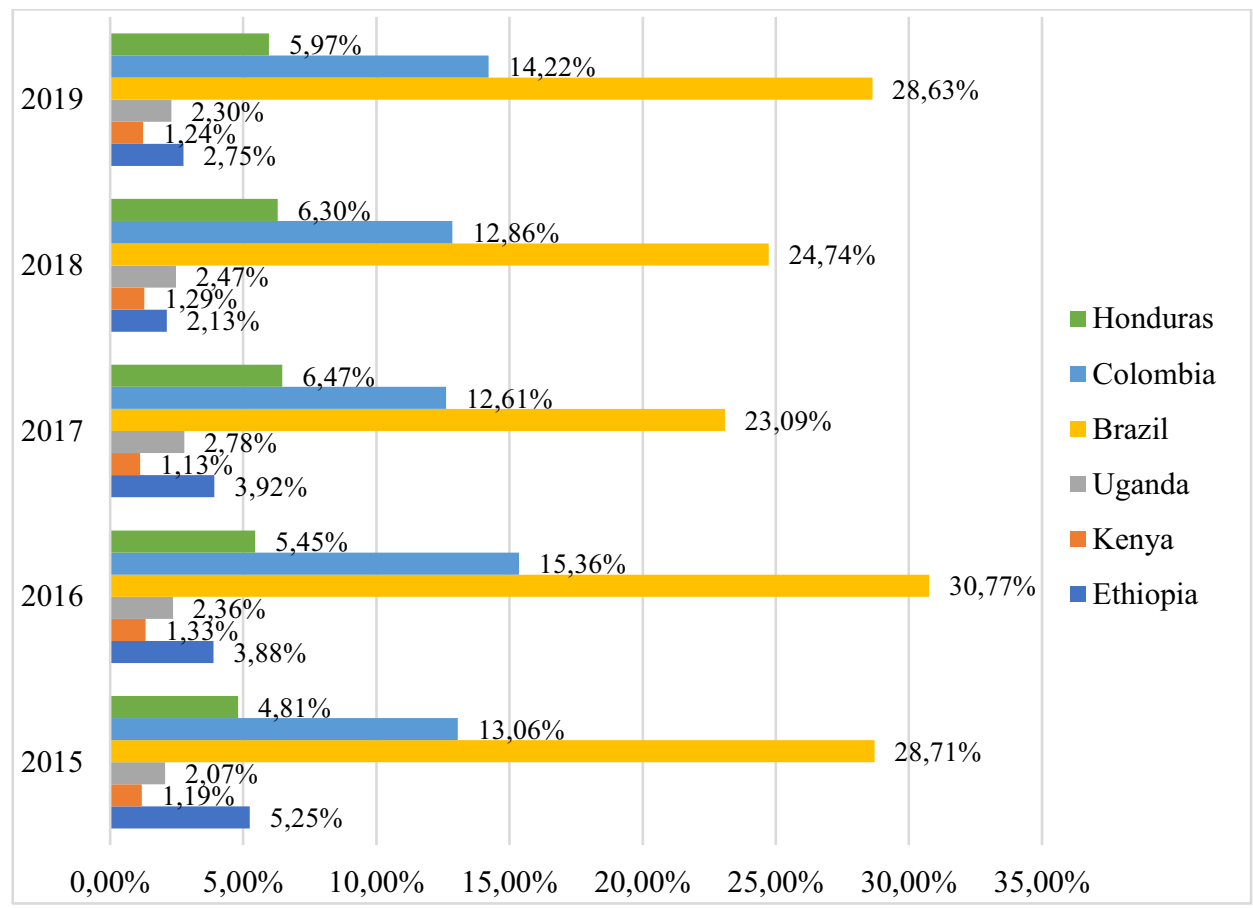

Fig. 1. Share of African and South American countries in world coffee exports, in percentage terms.

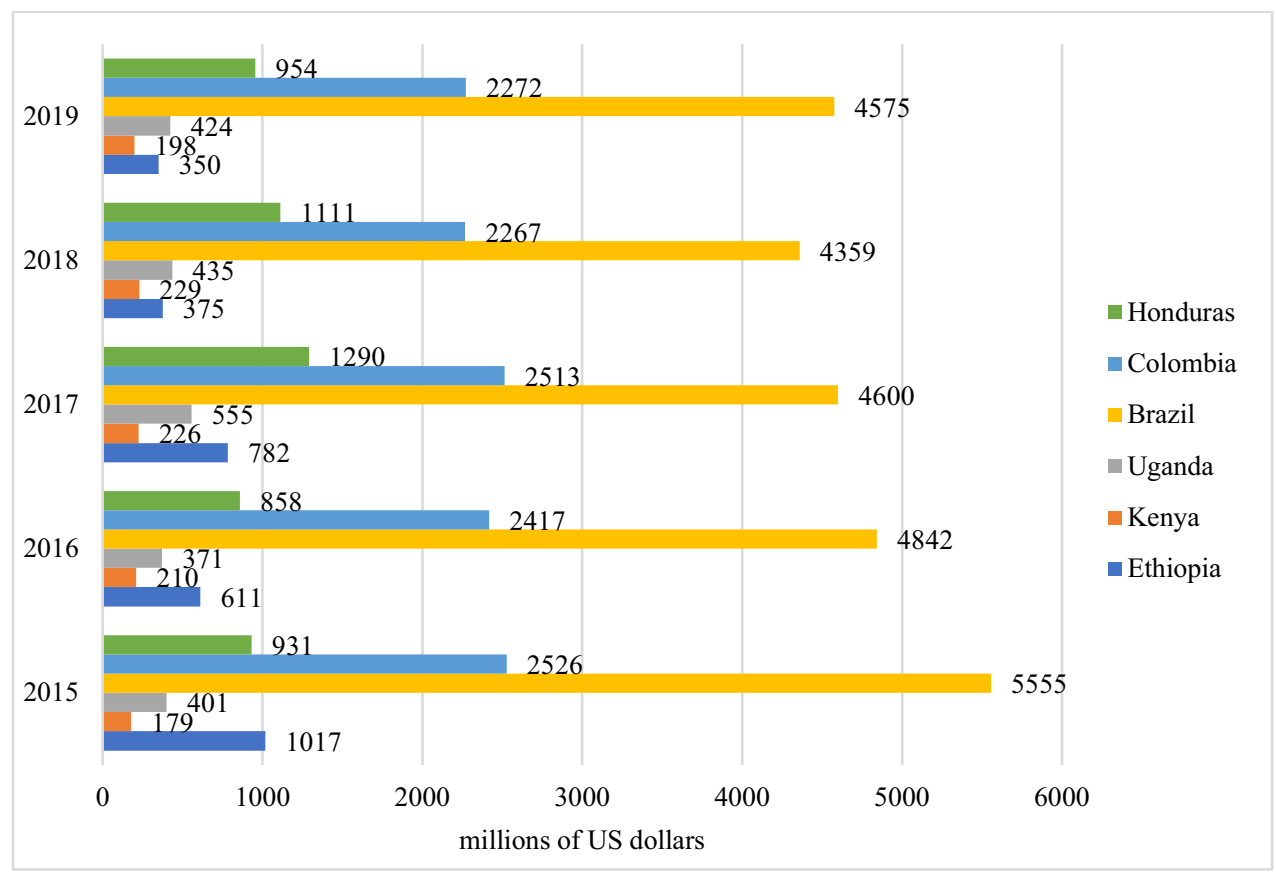

Fig. 2. African and South American coffee exports, in monetary terms.

In monetary terms, the total exports of these countries amounted to 1.039 billion US dollars in 2018 against 1.563 billion US dollars in 2017, which is 7 times less than those of Brazil, Colombia and Honduras combined in similar periods ( 7.737 billion US dollars 
in 2018 and 8.403 billion US dollars in 2017), despite the fact that the African raw material potential is not inferior to South American.

A key working tool for increasing the involvement of African countries in the global commodity flow can be the modernization of state support, expressed in the activities of organizations for the sale of raw materials to the international market. The goal of African Governments should not be the creation of fully controlled markets and their own exchanges, but the formation of a single continental system of institutions aimed at making Africa the world's main commodity exporter. An example is the system in Russia, a country with a transition economy, in which there were introduced the organizations that provide the information about competent access to international sales markets and direct business contacts to the producers of goods, as well as an assessment of real export opportunities. In addition, Russian exporters are provided with insurance coverage and guarantees against non-payments from buyers. Thus, the Russian Export Center provides consulting support on export transactions and promotes the products abroad. The Russian Export Agency insures the risks of non-compliance with the terms of delivery and confirmed letters of credit. Roseximbank provides affordable financing to sellers and issues independent guarantees to ensure the repayment of advance payments. State Corporation 'VEB.RF' coordinates the activities of state institutions to support the export of Russian-made goods, which includes financial and administrative measures. The Russian government provides subsidies to companies that sell their goods abroad, such as compensation for the costs of research activities, equipment purchases, infrastructure investments, and transportation costs. Banks that finance export transactions have the right to subsidize the lost income on export loans issued in the framework of ensuring international competitiveness.

The programs of state export support developed and implemented in Russia on the basis of Government Resolutions should be adapted in the countries of the African continent as follows (Table 1):

Table 1. Adaptation of Russian state export support programs in African countries.

\begin{tabular}{|c|c|c|c|c|}
\hline $\begin{array}{c}\text { Regulatory } \\
\text { document }\end{array}$ & $\begin{array}{l}\text { The basis of the } \\
\text { support } \\
\text { program }\end{array}$ & Support mechanisms & $\begin{array}{c}\text { Country } \\
\text { of } \\
\text { adaptation }\end{array}$ & $\begin{array}{l}\text { Implementation } \\
\text { result }\end{array}$ \\
\hline $\begin{array}{l}\text { Russian } \\
\text { Government } \\
\text { Resolution } \\
\text { №191 dated } \\
23.02 .2019\end{array}$ & $\begin{array}{l}\text { Improving } \\
\text { competitiveness, } \\
\text { increasing } \\
\text { production and } \\
\text { export volumes }\end{array}$ & $\begin{array}{l}\text { Investment loans for the } \\
\text { creation of export- } \\
\text { oriented production, } \\
\text { international factoring, } \\
\text { forfeiting, letters of } \\
\text { credit, loans to foreign } \\
\text { buyers and their banks. } \\
\text { The duration of the } \\
\text { program is from } 2 \text { to } 5 \\
\text { years. The maximum } \\
\text { amount of one loan is up } \\
\text { to } 60 \text { billion rubles for } \\
\text { investment loans and up } \\
\text { to } 30 \text { billion rubles for } \\
\text { other loans.[5] }\end{array}$ & Kenya & $\begin{array}{l}\text { Increase the } \\
\text { involvement of the } \\
\text { role of producers } \\
\text { in export } \\
\text { transactions by } \\
\text { providing access } \\
\text { to preferential } \\
\text { lending } \\
\text { mechanisms. } \\
\text { Increase in sales to } \\
\text { the final buyer } \\
\text { from } 15 \% \text { and } \\
\text { higher by not only } \\
\text { selling the goods } \\
\text { through a state } \\
\text { auction, but also } \\
\text { directly to a } \\
\text { foreign buyer. }\end{array}$ \\
\hline $\begin{array}{l}\text { Russian } \\
\text { Government } \\
\text { Resolution } \\
\text { №1368 } \\
\text { dated } \\
\end{array}$ & $\begin{array}{l}\text { Compensation } \\
\text { for the costs of } \\
\text { patenting abroad }\end{array}$ & $\begin{array}{l}\text { Subsidies to Russian } \\
\text { manufacturers to finance } \\
\text { part of the costs } \\
\text { associated with the } \\
\text { registration }\end{array}$ & Ethiopia & $\begin{array}{l}\text { Increase exports } \\
\text { by trading coffee } \\
\text { on international } \\
\text { exchanges by } \\
\text { issuing permits to }\end{array}$ \\
\hline
\end{tabular}




\begin{tabular}{|c|c|c|c|c|}
\hline 15.12 .2016 & & 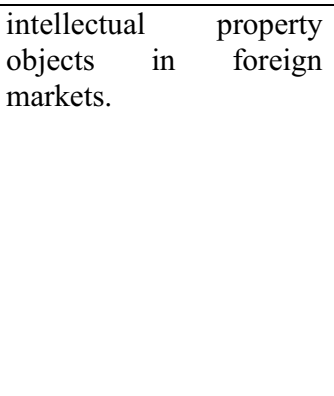 & & $\begin{array}{l}\text { Ethiopian sellers } \\
\text { to participate in } \\
\text { international } \\
\text { trading on ICE, } \\
\text { NYMEX and } \\
\text { LIFFE and } \\
\text { financing part of } \\
\text { the export } \\
\text { shipment costs } \\
\text { after the closing of } \\
\text { the exchange deal. }\end{array}$ \\
\hline $\begin{array}{l}\text { Russian } \\
\text { Government } \\
\text { Resolution } \\
\text { №496 dated } \\
26.04 .2017\end{array}$ & $\begin{array}{l}\text { Partial } \\
\text { compensation of } \\
\text { product } \\
\text { transportation } \\
\text { costs }\end{array}$ & $\begin{array}{l}\text { Support for } \\
\text { manufacturers of high- } \\
\text { tech products, namely, } \\
\text { reimbursement of up to } \\
80 \% \text { of the actual costs } \\
\text { incurred in transporting } \\
\text { products to foreign } \\
\text { markets. }\end{array}$ & Uganda & $\begin{array}{l}\text { The development } \\
\text { of the country's } \\
\text { foreign trade } \\
\text { system is not only } \\
\text { due to the } \\
\text { implementation of } \\
\text { raw material } \\
\text { quality control } \\
\text { programs by } \\
\text { UCDA, but also } \\
\text { due to covering } \\
\text { the costs of } \\
\text { farmers for } \\
\text { processing raw } \\
\text { materials and their } \\
\text { logistics to ports } \\
\text { in order to } \\
\text { modernize the } \\
\text { state's transport } \\
\text { infrastructure. }\end{array}$ \\
\hline
\end{tabular}

It seems necessary to use Russian tools for the development of export sales, taking into account the following features:

- maximum change in the export structure, paying special attention to producers.

- guaranteed state support, including preferential provision of the required equipment for coffee processing, and promotion of products on foreign markets.

- a combination of administrative and economic instruments, namely the provision of budget funds to exporters for the development of the infrastructure of the raw coffee market.

The programs should be implemented in conjunction with the elimination of tariff and non - tariff barriers to the export of products and the creation of special economic zones and technology parks with tax support, such as, for example, in Russia - the refund of valueadded tax on the export of goods abroad.

Thus, the introduction on the African continent of a model of favorable state regulation of exports of a country with a transition economy and its adaptation to the coffee business will be a key mechanism for unlocking the enormous potential of developing countries to become the main suppliers of raw materials in the global commodity flow.

The results of the influence of Governments in Africa in the coffee trade prove the need for the timely application of the above-mentioned accumulated international experience in this area in order to form a holistic systematic approach to improving market relations in African countries through the renewal of state export regulation programs on the basis of support from Russia. 


\section{References}

1. L.L. Fituni, Problems of the modern economy 3(47) (2013)

2. M. Sharov, Features of the coffee industry in Ethiopia. Tasty coffee journal (2019)

3. V. Demish, Features of the coffee industry in Kenya. Tasty coffee journal (2019)

4. S. Akhmetshina, Coffee industry in Uganda. Tasty coffee journal (2019)

5. State export support. State information system of industry (2019)

6. N. Vikhrova, E. Eliseeva, E. Sidorova, L. Korshunova, International Multidisciplinary Scientific GeoConference Surveying Geology and Mining Ecology Management, SGEM 5.2, 203-208 (2020)

7. G. Nurzhanova, G. Mussirov, S. Niyazbekova, et al., Entrepreneurship and Sustainability Issues 8(1), 656-671 (2020) DOI: 10.9770/jesi.2020.8.1(45)

8. T. Kreydenko, M. Chernyaev, E. Grigorieva, A. Korenevskaya, International Journal of Energy Economics and Policy 10(2), 504-511 (2020) DOI: 10.32479/ijeep. 9083 